\title{
PERATURAN KEBIJAKAN PENDIDIKAN DI INDONESIA PADA MASA ORDE LAMA, ORDE BARU, REFORMASI, DAN KABINET KERJA
}

\author{
Sarfika Datumula \\ Dosen Universitas Al-khairat Palu \\ sarpika@unisapalu.ac.id
}

\begin{abstract}
Abstrack
The education system as we know it today is the result of educational developments that have grown in the history of our nation's experience. There have been some writings discussing the regulations of education policy in Indonesia from time to time, but this paper examines the comparison of education policies from the Old Order era to the implementation of education policies to the work cabinet period. Through a literature review, this paper aims to describe how education policy regulations in Indonesia were during the Old Order, New Order, Reform, and Work Cabinet Periods. The results of this study reveal as has been explained in the discussion, that during the New Order era education only took place in terms of quantity without being matched by quality developments. In this period, it is to create as many educated graduates as possible without producing quality teaching and educational outcomes. The curricula used at this time were the 1968 curriculum, the 1975 curriculum, the 1984 curriculum, and the 1994 curriculum. However, education in the next period during the New Order period was not said to be fully successful, so in the next period of the reform period, improvements were needed, both in the field of curriculum. as well as in terms of the teaching staff. The curricula used in this reform era are the Competency-Based Curriculum (KBK) and the Education Unit Level Curriculum (KTSP), and K13.
\end{abstract}

Keywords: policy regulations, education in indonesia

Abstrak

Sistem pendidikan yang kita kenal sekarang adalah hasil perkembangan pendidikan yang tumbuh dalam sejarah pengalaman bangsa kita. Telah ada sejumlah tulisan membahas tentang peraturan kebijakan pendidikan di Indonesia pada masa ke masa, namun tulisan ini mengkaji perbandingan kebijakan pendidikan dari orde masa orde lama sampai pada penerapan kebijakan pendidikan hingga masa kebinet kerja. Melalui kajian kepustakaan, tulisan ini bertujuan untuk menggambarkan bagaimana peraturan kebijakan Pendidikan di Indonesia Pada Masa Orde Lama, Orde Baru, Reformasi, dan Kabinet Kerja. Hasil penelitian ini mengungkapkan seperti yang telah dijelaskan pada pembahasan, bahwa pada masa orde baru pendidikan hanya berlangsung dari segi kuantitas tanpa diimbangi dengan perkembangan kualitas. Pada masa ini adalah menciptakan lulusan terdidik sebanyak-banyaknya tanpa menghasilkan kualitas pengajaran dan hasil didikan. Adapun kurikulum yang digunakan pada masa ini yaitu kurikulum 1968, kurikulum 1975, kurikulum 1984 dan kurikulum 1994. Namun pendidikan pada masa berikutnya pada masa orde baru belum dikatakan berhasil sepenuhnya, maka pada masa berikutnya masa reformasi diperlukan adanya pembenahan-pembenahan, baik dalam bidang kurikulum maupun dari segi tenaga pengajarnya. Kurikulum yang dipakai pada era reformasi ini yaitu Kurikulum Berbasis Kompetensi (KBK) dan Kurikulum Tingkat Satuan Pendidikan (KTSP) dan K13.

Kata kunci: Peraturan Kebijakan, Pendidikan di Indonesia 


\section{Pendahuluan}

Pada dasarnya, landasan adalah suatu alas atau dasar pijakan dari sesuatu hal atau suatu titik tumpu atau titik tolak dari sesuatu hal atau suatu fundasi tempat berdirinya sesuatu hal. Pendidikan dalam arti luas adalah hidup, artinya segala pengalaman belajar di berbagai lingkungan yang berlangsung sepanjang hayat dan berpengaruh positif bagi perkembangan individu. Pendidikan dalam arti sempit identik dengan penyekolahan (schooling), yaitu pengajaran formal di bawah kondisi-kondisi yang terkontrol. Landasan pendidikan adalah seperangkat asumsi yang dijadikan titik tolak dalam rangka pendidikan. Landasan historis pendidikan adalah asumsi-asumsi pendidikan yang bersumber dari konsep dan praktek pendidikan masa lampau sejarah yang menjadi titik tolak perkembangan pendidikan masa kini dan masa datang. Dengan mengacu pada suatu landasan yang kokoh, pendidikan akan dapat dilaksanakan secara mantap, jelas arah tujuannya, relevan isi kurikulumnya, serta efektif dan efisien metode atau cara-cara pelaksanaannya.

Dalam proses pertumbuhan menjadi negara maju, Indonesia telah mengalami berbagai perubahan, termasuk bidang pendidikannya. Perubahan-perubahan itu merupakan hal yang wajar karena perubahan selalu dipengaruhi oleh berbagai faktor yang bisa berganti selaras dengan perkembangan serta tuntutan zaman pada saat itu. Tidaklah mengherankan apabila sistem pendidikan yang kita anut segera setelah merdeka adalah sistem kontinental karena kontak kita pada saat itu adalah dengan negara-negara Eropa, khususnya negeri Belanda Setelah kita merdeka dan menerapkan sistem pendidikan kontinental sekitar lima windu, kita dapati bahwa pendidikan dengan sistem Eropa tidak cocok lagi dengan tuntutan perkembangan zaman.

Masa lampau memperjelas pemahaman kita tentang masa kini. Sistem pendidikan yang kita kenal sekarang adalah hasil perkembangan pendidikan yang tumbuh dalam sejarah pengalaman bangsa kita. Telah ada sejumlah tulisan membahas tentang peraturan kebijakan pendidikan di Indonesia pada masa ke masa, namun tulisan ini mengkaji perbandingan kebijakan pendidikan dari orde masa orde lama samapai pada penerapan kebijakan pendidikan hingga masa kebinet kerja pemeritahan peresiden Joko Widodo. Dalam hal peneliti mengajukan pertanyaan yaitu Bagaimana kebijakan Pendidikan di Indonesia Pada Masa Orde Lama, Orde Baru, Reformasi, dan Kabinet Kerja ?

Untuk itu tulisan ini bertujuan untuk menggambarkan bagaimana peraturan kebijakan Pendidikan di Indonesia Pada Masa Orde Lama, Orde Baru, Reformasi, dan Kabinet Kerja. Melalui tulisan ini diharapkan adanya bahan pembanding dalam melihat perbandingan kebijakan pendidikan dari masa ke masa, dimana penelitian ini dapat menjadi kajian pembanding demi perbaikan kebijakan pedidikan di Indonesia pada masa-masa akan datang.

\section{Metode}


Jenis peelitian yang digunakan yaitu penelitian kepustakaan, dengan menggunakan literatur sesuai dengan objek kajian yang dikaji. Pelineliti melakukan pencarian data baik sumber primer maupun sekunder yang relevan dengan tema. Data yang terkumpul kemudian dilakukan dianalisis, interpretasi, penyajiaan data melalui dideskripsi, kemudian dilakukan penarikan kesimpulan.

\section{Pembahasan}

\section{Kebijakan Pendidikan Pada Masa Kemerdekaan sampai Orde Lama (1945-1969)}

Pada masa ini, usaha penting dari pemerintah Indonesia pada permulaan adalah tokoh pendidik yang telah berjasa dalam zaman kolonial menjadi menteri pengajaran. Dalam kongres pendidikan, Menteri Pengajaran dan Pendidikan tersebut membentuk panitia perancang RUU mengenai pendidikan dan pengajaran. Hal ini dimaksudkan untuk membentuk sebuah sistem pendidikan yang berlandaskan pada ideologi Bangsa Indonesia sendiri. Pemerintah Indonesia berupaya melaksanakan pendidikan nasional yang berlandaskan pada budaya bangsa sendiri. Tujuan pendidikan nasional adalah untuk menciptakan warga negara yang sosial, demokratis, cakap dan bertanggung jawab dan siap sedia menyumbangkan tenaga dan pikiran untuk negara. Praktek pendidikan selepas penjajahan menekankan pengembangan jiwa patriotisme. Praktek pendidikan tidak bisa dilepaskan dari lingkungan, baik lingkungan sosial, politik, ekonomi maupun lingkungan lainnya.

Tujuan dari pendidikan zaman kemerdekaan adalah untuk mengisi tata kehidupan dan pembangunan. Tujuan tersebut mengalami kendala, yaitu penjajah Belanda ingin menjajah kembali sehingga kondisi ini menuntut kembali bangsa Indonesia berjuang secara politik dan fisik.

Pada kondisi ini, pemerintah mulai mempersiapkan sistem pendidikan nasional sesuai amanat UUD 1945. Beberapa bulan setelah proklamasi kemerdekaan Menteri Pendidikan, Pengajaran dan Kebudayaan (PP dan K) mengeluarkan "Intruksi Umum" agar para guru membuang sistem pendidikan kolonial dan mengutamakan patriotisme. Selanjutnya, diawali dengan Kongres Pendidikan, Menteri PP dan K membentuk Komisi Pendidikan dan komisi ini membentuk Panitia Perancang Undang-Undang (RUU) mengenai pendidikan dan pengajaran. Karena terganggu dengan pecahnya perang kolonial kedua, pembahasan RUU di Badan Pekerja Komite Nasional Indonesia Pusat (BP KNIP) terhenti dan baru dapat dilaksanakan kembali pada tanggal 29 Oktober 1949. Tanggal 5 April 1950 RUU tersebut diundangkan sebagai UU RI No.4 Tahun 1950 Tentang DasarDasar Pendidikan dan Pengajaran di Sekolah. UU RI No.4 Tahun 1950 ini kemudian diterima oleh DPR pada tanggal 27 Januari1954, kemudian disyahkan oleh pemerintah pada tanggal 12 Maret 1954 dan diundangkan tanggal 18 Maret 1954 sebagai UU No.12 Tahun $1954 .^{1}$ 
Sekalipun terjadi pergantian bentuk dan konstitusi negara sebagaimana terjadi pada tanggal 18 Agustus 1945 PPKI menetapkan UUD 1945 sebagai Konstitusi Negara hingga pada akhirnya terbentuk Republik Indonesia Serikat (RIS) yang memberlakukan UUD RIS, Pada saat RIS kembali ke negara kesatuan RI, UUD RIS diganti dengan UUD Sementara RI atau UU No. 7 Tahun 1950, tetapi pendidikan nasional Indonesia tetap dilaksanakan sesuai jiwa UUD 1945, dan bahwa UU RI No.4 Tahun 1950 de fakto digunakan sebagai pedoman penyelenggaraan pendidikan, pengajaran, kebudayaan untuk seluruh daerah Negara Kesatuan Republik Indonesia. ${ }^{2}$

Dalam UU No 4/1950 Bab II, pasal, tujuan pendidikan nasional Indonesia adalah membentuk manusia susila yang cakap dan warga negara yang demokratis serta bertanggung jawab tentang kesejahteraan masyarkat dan tanah air.

\section{Struktur persekolahan dan Kurikulum Pendidikan pada masa awal kemerdekaan}

Tata susunan persekolahan sesudah Indonesia merdeka yang berdasarkan satu jenis sekolah untuk tiga tingkat pendidikan seperti pada zaman Jepang tetap diteruskan sedangkan rencana pembelajaran pada umumnya sama dan bahasa Indonesia ditetapkan sebagai bahasa pengantar untuk sekolah. Buku-buku pelajaran yang digunakan adalah buku-buku hasil terjemahan dari bahasa Belanda ke dalam bahsa Indonesia yang sudah dirintis sejak jaman Jepang. Adapun susunan persekolahan dan kurikulum yang berlaku sejak tahun 1945-1950 adalah sebagai berikut:

1. Pendidikan Rendah

Pendidikan yang terendah di Indonesia sejak awal kemerdekaan yang disebut dengan Sekolah Rakyat (SR) lama pendidikannya semula 3 tahun. Maksud pendirian SR ini adalah selain meningkatkan taraf pendidikan pada masa sebelum kemerdekaan juga dapat menampung hasrat yang besar dari mereka yang hendak bersekolah. Mengingat kurikulum SR diatur sesuai dengan putusan Menteri PKK tanggal 19 nopember 1946 NO 1153/Bhg A yang menetapkan daftar pelajaran SR dimana tekanannya adalah pelajaran bahasa berhitung. Hal ini dapat telihat bahawa dari 38 jam pelajaran seminggu, 8 jam adalah untuk bahasa Indonesia, 4 jam untuk bahasa daerah dan 17 jam berhitung untuk kelas IV $<$ V dan VI. Tercatat sejumlah 24.775 buah SR pada akhir tahun 1949 pada akhir tahun 1949 di seluruh Indonesia. ${ }^{3}$

2. Pendidikan Guru

Dalam periode antara tahun 1945-1950 dikenal tiga jenis pendidikan guru yaitu:

a. Sekolah Guru B (SGB) lama pendidikan 4 tahun dan tujuan pendidikan guru untuk sekolah rakyat. Murid yang diterima adalah tamatan SR yang akan lulus dalam ujian masuk sekolah lanjutan. Pelajaran yang diberikan bersifat umum untuk di kelas I,II,III sedangkan pendidikan keuruan baru diberikan di kelas IV. Untuk kelas IV ini juga dapat diterima tamatan sekolah SMP,SPG dipimpin oleh 
seorang kepala sekolah yang membawahinya sejumlah guru dan diantaranya merupakan tenaga tidak tetap karena memang sangat kekuarangan guru tetap. Adapun sistem ujian pelaksanaannya dipecah menjadi dua yaitu, perta ditempuh di kelas II dan ujian kedua di kelas IV.

b. Sekolah Guru C (SGC) berhubung kebutuhan guru SR yang mendesak maka terasa perlunya pembukaan sekolah guru yang dalam tempo singkat dapat menghasilkan. Untuk kebutuhan tersebut didirikan sekolah guru dua tahun setelah SR dan di kenal dengan sebutan SGC tetapi karena dirasakan kurang bermanfaat kemudian ditutup kembali dan diantaranya dijadikan SGB.

c. Sekolah guru A (SGA) karena adanya anggapan bahwa pendidikan guru 4 tahun belum menjamin pengetahuan cukup untuk taraf pendidikan guru, maka dibukalah SGA yang memberi pendidikan tiga tahun sesudah SMP. Disamping Itu dapat pula diterima pelajar-pelajar dari lulusan kelas III SGB. Mata pelajaran yang diberikan di SGA sama jenisnya dengan mata pelajaran yang diberikan di SGB hanya penyelenggaraannya lebih luas dan mendalam. ${ }^{4}$

3. Pendidikan Umum

Ada dua jenis pendidikan Umum yaitu sekolah menengah pertama (SMP) dan sekolah menengah Tinggi (SMT).

a. Sekolah Menengah Pertama (SMP) seperti halnya pada zaman jepang, SMP mempergunakan rencana pelajaran yang sama pula, tetapi dengan keluarnya surat keputusan menteri PPK thun 1946 maka diadakannya pembagian A dan B mulai kelas II sehingga terdapat kelas II A,IIB, IIIA dan IIIB. Dibagian A diberikan juga sedikit ilmu alam dan ilmu pasti. Tetapi lebih banayak diberikan pelajaran bahasa dan praktek administrasi. Dibagian B sebaliknya diberikan Ilmu Alam dan Ilmu Pasti.

b. Sekolah Menengah Tinggi (SMT), Kementerian PPK hanya mengurus langsung SMAT yang ada di jawa terutama yang berada di kota-kota sperti: Jakarta,bandung, semarang, Yogyakarta, Surakarta, Surabaya dan Cirebon. SMT di Luar Jawa berada di bawah pengawasan pemerintah daerah berhubung sulitnya perhubungan dengn pusat. SMT merupakan pendidikan tiga tahun setelah SMP dan setelah lulus dapat melanjutkan ke perguruan tinggi. Mengenai rencana pelajaran belum jelas, dan yang diberikan adalah rencana pelajaran dalam garis besar saja. Karena pada waktu itu msaih harus menyesuaikan dengan keadaan zaman yang masih belum stabil. Demikian rencana pembelajaran yang berlaku yaitu: (1) isinya memenuhi kebutuhan nasional, (2) bahasa pengantarnya adalah bahasa Indonesia, (3) mutunya setingkat dengan SMT menjelang kemerdekaan. Ujian akhir dapat diselenggarakan oleh masing-masing sekolah

${ }^{4}$ Rianti Nugroho, Pendidikan Indonesia: Harapan, Visi,dan Strategi, (Jogjakarta: Pustaka Pelajar, 2008),15-16. 
selama belum ada ujian negara, tetapi setelah tahun 1947 barulah berlaku ujian negara tersebut. ${ }^{5}$

4. Pendidikan Kejuruan

Pendidikan kejuruan adalah Pendidikan ekonomi dan pendidikan kewanitaan.

a. Pendidikan ekonomi

Pada awal kemerdekaan pemerintah baru dapat membuka sekolah dagang yang lama, pendidikannya tiga tahun sesudah Sekolah Rakyat. Sekolah dagang ini bertujuan untuk memenuhi kebutuhan tenaga administrasi atau pembukuan, sedangkan penyelenggaraan sekolah dagang tersebut dilaksanakan oleh inspektur sekolah dagang.

b. Pendidikan Kewanitaan

Sesudah kemerdekaan pemerintah membuka Sekolah Kepandaian Putri (SKP) dan pada tahun 1947 sekolah guru kepandaian putri (SGKP) yang lama pelajaranya empat tahun setelah SMP atau SKP. ${ }^{6}$

5. Pendidikan Teknik

a. Kursus Kerajinan Negeri $(\mathrm{KKN})$, sekolah/kursus in lamamnya satu tahun lamanya dan merupakan pendidikan teknik terendah berdasarkan SR enam tahun. KKN terdiri atas jurusan-jurusan: kayu, besi,anyaman.perabot rumah, las dan batu.

b. Sekolah Teknik Pertama (STP), bertujuan mendapatkan tenaga tukang yang terampil tetapi disertai dengan pengetahuan teori. Lama pendidikan ini dua tahun sesudah SR dan terdiri atas jurusam-jurusan: kayu, batu, keramik, perabot rumah, anyaman, besi ,listrik, mobil, cetak, tenun kulit, motor, ukur tanah dan cor.

c. Sekolah Teknik (ST), bertujuan mendidik tenaga-tenaga pengawasan bangunan. Lama pendidikan dua tahun stelah STP atau SMP bagian B dan meliputi jurusan-jurusan: bangunan gedung, bangunan air dan jalan, bangunan radio, bangunan kapal, percetakan dan pertambangan.

6. Sekolah Teknik menengah (STM)

Bertujuan mendidik tenaga ahli teknik dan pejabat-pejabat teknik menengah. Lama pendidikan empat tahun setelah SMP bagian B atau ST dan terdiri atas jurusn-jurusan: bangunnan gedung, bangunan sipil, bangunan kapal, bangunan mesin, bangunan mesin, bangunan listrik, bangunan mesin kapal, kimia, dan pesawat terbang.

Pendidikan guru untuk sekolah-sekolah teknik, untuk memenuhi keperluan guruguru sekolah teknik, dibuka sekolah/kursus-kursus untuk mendidik guru yang menghasilkan:

a. Ijazah A Teknik (KGSTP) guna mengajar dengan wewenang penuh pada STP dalam jurusan: bangunan sipil, mesin, listrik dan mencetak. 
b. Ijazah B I Teknik (KGST) untuk mengajar dengan wewenang penuh pada ST/STM kelas I dalam jurusan bangunan sipil, bangunan gedung-geung dan mesin.

c. Ijazah B II Teknik guna mengajar dengan wewenang penuh pada STM dalam jurusan bangunan sipil, bangunan gedung, mesin dan listrik. ${ }^{7}$

7. Pendidikan Tinggi

Dalam periode 1945-1950 kesempatan untuk meneruskan studi pendidikan tinggi semakin terbuka lebar bagi warga negara tanpa syarat. Lembaga pendidikan ini berkembang pesat tetapikarena adanya pelaksanaannya di lakukan perjuangan fisik maka perkuliahan kerap kali di sela dengan perjuangan garis depan.

Lembaga pendidikan yang ada adalah Universitas Gajah Mada, beberapa sekolah tinggi dan akademi di Jakarta (daerah kependudukan) Klaten, Solo dan Yogyakarta. ${ }^{8}$

8. Pendidikan Tinggi Republik

Sejak awal kemerdekaan di Jakarta pada waktu merupakan daerah pendudukan Belanda, berdiri sekolah Tinggi kedokteran sebagai kelanjutan Ika Daigaku zaman Jepang. Pada bulan Nopember 1946 dibuka pula Sekolah Tinggi Hukum serta filsafat dan sastra. Setelah aksi agresi militer I kedua lembaga pendidikan tinggi terakhir ini di tutup oleh belanda sehingga secara resmi sudah tidak ada lagi, dengan demikian pendidikan tinggi waktu itu terpecah menjadi dua yaitu pendidikan tinggi republik dan Pendidikan tingkat tinggi pendudukan belanda. Tetapi kuliah-kuliah masih dilanjutkan di rumah-rumah dosen sehingga merupakan semacam kuliah privat. Sebelum agresi militer I di Malang terdapat pula lembaga pendidikan tinggi republik, dengan adanya. Demikian pula terdapat sekolah tinggi kedokteran hewan sekolah tinggi teknik di Bandung dipindahkan ke Yogyakarta.

9. Pendidikan Tinggi di Daerah Pendudukan Belanda

Atas prakarsa pihak belanda pada bulan Januari 1946 didirikan suatu universitas darurat (NOOD Universiteit) yang terdiri dari lima fakultas yaitu fakultas-fakultas kedokteran, hukum, sastra dan filsafat dan pertanian di jakarta dan fakultas teknik di bandung.

Pada bulan Maret 1947 oleh pemerintah belanda secaea resmi nama universitas darurat diganti dengan nama Universitas Indonesia (Universiteit Van Indonesie). Oada Tahun 1947 juga universitas tersebut di perluas dengan fakultas ilmu pasti dan alam di Bandung, kedokteran hewan di Bogor, Kedokteran di Surabaya dan Ekonomi di maksar (Ujung Pandang). Pada Bulan maret 1948 fakutas pertanian di pindahkan ke Bogor. ${ }^{10}$

\section{Pendidikan Masa Orde Lama}

Secara umum pendidikan orde lama sebagai wujud interpretasi pasca kemerdekaan di bawah kendali kekuasaan Soekarno cukup memberikan ruang bebas terhadap

${ }^{7}$ Ibid, 21

8Ibid, 22

${ }^{9}$ Moh. Yamin, Menggugat Pendidikan Indonesia (Jogjakarta: Ar Ruz, 2009), 36.

${ }^{10} \mathrm{Ibid}, 41$. 
pendidikan. Pemerintahan yang berasaskan sosialisme menjadi rujukan dasar bagaimana pendidikan akan dibentuk dan dijalankan demi pembangunan dan kemajuan bangsa Indonesia di masa mendatang. Pada prinsipnya konsep sosialisme dalam pendidikan memberikan dasar bahwa pendidikan merupakan hak semua kelompok masyarakat tanpa memandang kelas sosial.

Pada masa ini Indonesia mampu mengekspor guru ke negara tetangga, dan banyak generasi muda yang disekolahkan di luar negeri dengan tujuan agar mereka kelak dapat kembali ke tanah air untuk mengaplikasikan ilmu yang telah mereka dapat. Tidak ada halangan ekonomis yang merintangi seseorang untuk belajar di sekolah, karena diskriminasi dianggap sebagai tindakan kolonialisme. Pada saat inilah merupakan suatu era di mana setiap orang merasa bahwa dirinya sejajar dengan yang lain, serta setiap orang memiliki hak untuk mendapatkan pendidikan. Orde lama berusaha membangun masyarakat sipil yang kuat, yang berdiri di atas demokrasi, kesamaan hak dan kewajiban antara sesama warga negara, termasuk dalam bidang pendidikan.

Banyak pemikir-pemikir yang lahir pada masa itu, sebab ruang kebebasan betulbetul dibuka dan tidak ada yang mendikte peserta didik. Tidak ada nuansa kepentingan politik sektoral tertentu untuk menjadikan pendidikan sebagai alat negara maupun kaum dominan pemerintah. Seokarno pernah berkata: “....sungguh alangkah hebatnya kalau tiap-tiap guru di perguruan taman siswa itu satu persatu adalah Rasul Kebangunan! Hanya guru yang dadanya penuh dengan jiwa kebangunan dapat 'menurunkan' kebangunan ke dalam jiwa sang anak,"

Dari perkataan Soekarno itu sangatlah jelas bahwa pemerintahan orde lama menaruh perhatian serius yang sangat tinggi untuk memajukan bangsanya melalui pendidikan.

Di bawah menteri pendidikan Ki Hadjar Dewantara dikembangkan pendidikan dengan sistem "among" berdasarkan asas-asas kemerdekaan, kodrat alam, kebudayaan, kebangsaan, dan kemanuasiaan yang dikenal sebagai "Panca Dharma Taman Siswa" dan semboyan "ing ngarso sung tulodho, ing madyo mangun karso, tut wuri handayani” pada 1950 diundangkan pertama kali peraturan pendidikan nasional yaitu UU No. 4/1950 yang kemudian disempurnakan (jo) menjadi UU No. 12/1954 tentang dasar-dasar pendidikan dan pengajaran di sekolah. Pada 1961 diundangkan UU No. 22/1961 tentang Pendidikan Tinggi, dilanjutkan dengan UU No.14/1965 tentang Majelis Pendidikan Nasional, dan UU No. 19/1965 tentang Pokok-Pokok Sitem Pendidikan Nasional Pancasila. Pada masa akhir pendidikan Presiden Soekarno, $90 \%$ bangsa Indonesia berpendidikan SD. ${ }^{11}$ Kurikulum pendidikan pada masa Orde Lama sebagai berikut :

1. Rentang Tahun 1945-1968

Kurikulum pertama yang lahir pada masa kemerdekaan memakai istilah dalam bahasa Belanda "leer plan" artinya rencana pelajaran. Perubahan arah pendidikan lebih bersifat politis, dari orientasi pendidikan Belanda ke kepentingan nasional. Sedangkan,

${ }^{11}$ http://www.unindra.ac.id/?q=node/31, Diakses 11 Desember 2020 
asas pendidikan ditetapkan Pancasila. Kurikulum yang berjalan saat itu dikenal dengan sebutan "Rencana Pelajaran 1947", yang baru dilaksanakan pada tahun 1950. Orientasi Rencana Pelajaran 1947 tidak menekankan pada pendidikan pikiran. Yang diutamakan adalah pendidikan watak, kesadaran bernegara dan bermasyarakat.

Pada masa tersebut siswa lebih diarahkan bagaimana cara bersosialisasi dengan masyarakat. Proses pendidikan sangat kental dengan kehidupan sehari-hari. Aspek afektif dan psikomotorik lebih ditekankan dengan pengadaan pelajaran kesenian dan pendidikan jasmani. Oleh karena itu, yang lebih penting adalah bagaimana menumbuhkan kesadaran bela negara. ${ }^{12}$

\section{Rencana Pelajaran Terurai 1952}

Kurikulum ini lebih merinci setiap mata pelajaran yang disebut "Rencana Pelajaran Terurai 1952”. Silabus mata pelajarannya jelas sekali, dan seorang guru mengajar satu mata pelajaran. Pada masa ini memang kebutuhan peserta didik akan ilmu pengetahuan lebih diperhatikan, dan satuan mata pelajaran lebih dirincikan. Namun, dalam kurikulum ini siswa masih diposisikan sebagai objek karena guru menjadi subjek sentral dalam pentransferan ilmu pengetahuan. Guru yang menentukan apa saja yang akan diperoleh siswa di kelas, dan guru pula yang menentukan standar-standar keberhasilan siswa dalam proses pendidikan. ${ }^{13}$

3. Kurikulum 1964

Fokus kurikulum 1964 adalah pada pengembangan daya cipta, rasa, karsa, karya, dan moral (Panca wardhana). Mata pelajaran diklasifikasikan dalam lima kelompok bidang studi: moral, kecerdasan, emosional/artistik, keterampilan, dan jasmaniah. Pendidikan dasar lebih menekankan pada pengetahuan dan kegiatan fungsional praktis. Pada kurikulum 1964 ini, arah pendidikan mulai merambah lingkup praksis. Dalam pengertian bahwa setiap pelajaran yang diajarkan disekolah dapat berkorelasi positif dengan fungsional praksis siswa dalam masyarakat.

Dalam masa transisi yang singkat RIS menjadi RI tidak memungkinkan pemerintah melaksanakan pendidikan dan pengajaran yang komprohensif yang berlaku untuk seluruh tanah air. Belanda meninggalkan sekolah kolonial di daerah yang dikuasai oleh pemerintah RI telah mulai dilaksanakan sistem pendidikan pendidikan yang direncanakan akan berlaku secara nasional dengan segala kemampuan yang terbatas. ${ }^{14}$

Setelah RIS terbentuk pada bulan Desember 1949 pemerintah RIS dan pemerintah RI yang menjadi inti dari negara kesatuan dan mempunyai aparat relatif paling lengkap menandatangani suatu "Piagam Persetujuan Pemerintah Republik Indonesia Serikat dan Pemerintah Republik Indonesia". Piagam ini ditanda tangani oleh Perdana Menteri Republik Indonesia Drs. Moh Hatta dan perdana menteri Republik Indonesia Dr. A Halim pada tanggal 19 Mei 1950.

12 http://www.unindra.ac.id/?q=node/31, Diakses 11 Desember 2020

13 http://www.unindra.ac.id/?q=node/31, Diakses 11 Desember 2020

${ }^{14}$ Umasih, Ketika Kebijakan Orde Lama Memasuki Domain Pendidikan: Penyiapan Dan Kinerja Guru Sekolah Dasar Di Indonesia, Vol 24, No 1 (2014), 12. 
Atas dasar piagam ini ada kaitan khusus dengan penyelenggraan pendidikan dan pengajaran Kementerian Pendidikan Pengajaran dan Kebudayaan RIS dan Kementerian Pendidikan Pengajaran dan Kebudayaan RI mengadakan "pengumuman Bersama pada tanggal 30 Juni 1950 yang bertujuan untuk sementara tahun ajaran 1950/1951 sistem pengajaran yang berlaku dalam RI dahului berlaku untuk seluruh Indonesia sampai sistem itu ditinjau kembali. Pelaksanaan UU Pokok Pendidikan dan Pengajaran

Mengenai pelaksanaan UU No 4 tahun 1950 (juncto UU no 12 tahun 1954) dapat dilihat pada beberapa jenis pendidikan dan kegiatannya yaitu:

a. Pendidikan Jasmani

Di indonesia departemen olahraga mengejar prestasi olahraga. Sikap ambivalensi ini dapat dilihat dari UGM yang memasukkan jurusan pendidikan jasmani dalam fakultas sastar. Pendagogik dan filsafat yang berarti dalam ilmu kerohanian (Geiisteswissenshafft). Di UI yang aakademi pendidian jasamaninya ada di bandung dimasukkan dalam fakultas kedokteran artinya digolongkan dalam ilmu alam (naturrwissenchafft).

b. Pendidikan Orang Dewasa

Pendidikan orang dewasa ini lebih dikenal dengan pendidikan masayarakat yang diselenggarakan oleh jawatan pendidikan masyarakat. Kegiatan pendidikan masyarakat ditentukan menurut kebjakan pemerintah berdasarkan atas surat keputusan menteri PP dan K tanggal 15 Februari 1961 Nomor 4223/Kab. Dalam pasal 17 disebutkan:

1) Merencanakan, memimpin, menggiatkan dan mengawasi pemberantasan buta huruf.

2) Merencanakan, memimpin, menggiatkan dan mengawasi pengetahuan umum

3) Mengusahakan buku-buku untuk mengisi perpustakaan rakyat.

4) Mengikuti dan mrmbantu perkembanagan gerakan pramuka

5) Mengusahakan buku-buku pimpinan dan pelajaran untuk pemberantasan buta huruf, serta buku-buku dan majalah-majalah untuk memelihara dan memperdalam kecakapan membaca dan menulis

6) Memimpin dan mengawasi pendidikan jasmani di luar sekolah

7) Menyelenggarakan kursus-kursus kader untuk pendidikan masyarakat.

8) Memajukan dan membantu gerakan kepanduan

9) Membantu inisiatif masyarakat untuk memajukan kaum wanita.

c. Pendidikan Luar Biasa. ${ }^{15}$

Berdasarkan surat keputusan menteri PP dan K nomor /Kab. Tanggal 9 Agustus 1953 jawatan pengajaran membentuk sebuah instansi urusan Pendidikan Luar Biasa yang bertugas "mengatur, mengurus dan mengawasi penyelenggaraan pendidikan luar bias di Indonesia". Inspeksi pendidikan guru pun mempunyai 
"inspeksi sekolah guru luar biasa" yang ditandatangani oleh Pendidikan Luar Biasa ini ilaha para tuna netra, tuna rungu, tuna wicara dan lemah ingatan bahkan anakanak cacad tubuh seperti Yayasan Pemeliharaan Anak-Anak Cacad dari Dr. Soeharso. Kebanyakan pendidikan semacam ini banyak dikelola oleh yayasanyayasan sedangkan pemerintah turut memberi bantuan material, fungsional dan tenaga pengajar.

\section{d. Pendidikan Guru}

Pada tahun 1951 jawatan pengajaran telah membuat rencana 10 tahun kewajiban belajar. Diperkirakan pada tahun itu jumlah anak yang bersekolah kira-kira sebesar 5.921.200. Untuk itu diperkirakan diperlukan tenaga guru sebesar 118.424 orang. Untuk maksud tersebut diperlukan pengadaan guru yamg amat mendesak. Sehubungan dengan itu kementerian PP dan $\mathrm{K}$ melalui kerjasama PGRI menyelenggarakan pendidikan guru darurat yaitu berupa kursus-kursus yang berbnetuk kursuss pengajar untuk kursusu pengantar kewajiban balajar atau di singkat KPKPKB. Di setiap kabupaten terdapat dua KPKPKB dengan masingmasing murid 80 orang.

e. Pendidikan kejuruan

Setelah Indonesia merdeka pendidikan kejuruan masih elatif terbelakang dibandingkan debgabn pendidikan umum. Kendala-kendalanya anrara lain karena pendidikan umum masih menjanjikan kemungkinan untuk memperolah pendidikan setinggi-tingginya disamping itu lowongan pekerjaan ketika itu masih terbuka. Selain itu peralatan tidak mencukupi, tenaga pengajar kurang dan pemahaman masyarakat sendiri terhadap manfaat pendidikan kejuruan itu belum banyak sehingga mereka enggan menyekolahkan anak-anaknya ke sekolah kejuruan. ${ }^{16}$

Sehubungan dengan kurangnya alat pendidikan maka pada tahun 1951 pemerintah dengan bantuan luar negeri mencoba memesan alat-alat untuk sekolah teknik, tetapi setelah bantuan ada pelaksaaannya tidak lancar karena tidak ada tenaga yang menggunakannya dan infrastruktur berupa gedung masih belum tersedia.

f. Pendidikan wanita

UU Nomor 4 tahun 1950 membuka kesempatan seluas-luasnya bagi para kaum wanita untuk mengikuti semua jenis dan jenjang pendidikan sehiingga dapat menjamin kehidupan mereka dalam masyarakat sebagai WNI yang sederajat dengan kaum pria. Sehubungan dengan itu selain sekolah-sekoah umum yang dapat diikuti oleh kaum wanita sampai ke jenjang setinggi-tingginya. Ketika itu pemerintah menyelenggarakan pula pendidikan-pendidikan kejuruan wanita seperti Sekolah Kepandaian Puteri (SKP)

${ }^{16}$ Muh. Said dan Junima Affan, Mendidik dari Zaman ke Zaman, (Bandung: Jemmars, 1999), 28 
dan Sekolah Guru kepandaian Puteri (SGKP). Di SKP dibuka kejuruan-kejuruan seperti menjahit, memasak, kerajianan tangan, memimpin rumah tangga, mengasuh anak.

g. Pendidikan Agama

Berdasarkan peraturan bersama Menteri PP dan K dan Menteri Agama maka di setiap sekoah rendah dan sekolah lanjutan (umum dan kejuruan) diberi pendidikan agama sebanyak dua minggu sekali saejak di kelas IV kecuali untuk lingkungan istimewa diberikan sejak kelas I. Pendidikan agama diberikan menurut agama murud masing-masing. Guru-guur agama diangkat dan diberhentikan oleh Menteri Agama serta biaya pendidikan di tanggung oleh kementerian agama. Yang nantinya sistem ini juga berlaku di sekolah-sekolah swasta jika pengurusnya mengkehendakinya dan orang tua murid memintanya. ${ }^{17}$

h. Pendidikan Tinggi

Dalam rangka pelaksanaan UU darurat Nomor 7 Ferbruari 1950, dibentuklah Universitas Indonesia dengan Ir. Surachman sebagai presiden (rektor) Universitas ini merupakan gabungan anatara balai Perguruan Tinggi Republik Indonesia dengan Universiteit van Indonesie, termasuk cabang-cabangnya dari berbagai fakultas di Bogor, Bandung, Surabaya dan Makasar.

i. Pendidikan Swasta

Pada zaman koonial Belanda mengijinkan berdiri sekolah-sekolah swata yang diselenggarakan oleh misi katolik dan zending Protestan. Namun demikian terhadap masyarakat islam yang sejak lama mempunyai lembaga-lembaga pendidikan tersendiri seperti madrasah-madrasah, pemerintah kolonial melakukan kebijakan politik van onthouding (politik tidak campur). ${ }^{18}$

Dalam masa kemerdekaan terutama dalam periode antara tahun 1950-1959 bermunculan sekolah swasta, baik yang baru berdri ataupun melanjutkan kembali sekolah-sekolah swata yang pernah ada sebelumnya. Sekolah-sekolah swata itu tidak ahnya atas dasar agama isalam seperti Muhamadiyah tetapi juga atas dasar aagama protestan dan katolik.

Meskipun ada lembaga pendidikan dari berbagai bidang dan jenjang pendidikan yang diselenggarakan oleh pihak swata ini, pemerintah PP dan $\mathrm{K}$ tetap melakukan tugas koordinasi. Selain memberikan subsidi untuk sekolah swata yang belum memenuhi syarat, pemerintah juga menyediakan tenaga-tenaga pengajar untuk diperbantukan.

\footnotetext{
${ }^{17}$ Ibid.,

${ }^{18}$ https://makalah-ibnu.blogspot.com/2009/12/ sistem-pendidikan-pada-masa-ordelama.html\#axzz6GWrGyL6G, Diakses 11 Desember 2020
} 


\section{Pendidikan Pada Masa Orde Baru}

Orde baru berlangsung dari tahun 1968 hingga 1998, dan dapat dikatakan sebagai era pembangunan nasional. Dalam bidang pembangunan pendidikan, khususnya pendidikan dasar, terjadi suatu loncatan yang sangat signifikan dengan adanya Instruksi Presiden (Inpres) Pendidikan Dasar. Namun, yang disayangkan adalah pengaplikasian inpres ini hanya berlangsung dari segi kuantitas tanpa diimbangi dengan perkembangan kualitas. Yang terpenting pada masa ini adalah menciptakan lulusan terdidik sebanyakbanyaknya tanpa memperhatikan kualitas pengajaran dan hasil didikan.

Pelaksanaan pendidikan pada masa orde baru ternyata banyak menemukan kendala, karena pendidikan orde baru mengusung ideologi "keseragaman" sehingga memampatkan kemajuan dalam bidang pendidikan. EBTANAS, UMPTN, menjadi seleksi penyeragaman intelektualitas peserta didik.

Pada pendidikan orde baru kesetaran dalam pendidikan tidak dapat diciptakan karena unsur dominatif dan submisif masih sangat kental dalam pola pendidikan orde baru. Pada masa ini, peserta didik diberikan beban materi pelajaran yang banyak dan berat tanpa memperhatikan keterbatasan alokasi kepentingan dengan faktor-faktor kurikulum yang lain untuk menjadi peka terhadap lingkungan. Beberapa hal negatif lain yang tercipta pada masa ini adalah, produk-produk pendidikan diarahkan untuk menjadi pekerja. Sehingga, berimplikasi pada hilangnya eksistensi manusia yang hidup dengan akal pikirannya (tidak memanusiakan manusia), Lahirnya kaum terdidik yang tumpul akan kepekaan sosial, dan banyaknya anak muda yang berpikiran positivistic, dan hilangnya kebebasan berpendapat. ${ }^{19}$

Pemerintah orde baru yang dipimpin oleh Soeharto megedepankan motto "membangun manusia Indonesia seutuhnya dan Masyarakat Indonesia". Pada masa ini seluruh bentuk pendidikan ditujukkan untuk memenuhi hasrat penguasa, terutama untuk pembangunan nasional. Siswa sebagai peserta didik, dididik untuk menjadi manusia "pekerja" yang kelak akan berperan sebagai alat penguasa dalam menentukan arah kebijakan negara. Pendidikan bukan ditujukan untuk mempertahankan eksistensi manusia, namun untuk mengeksploitasi intelektualitas mereka demi hasrat kepentingan penguasa.

Kurikulum-kurikulum yang digunakan pada masa orde baru yaitu sebagai berikut:

\section{Kurikulum 1968}

Kurikulum 1968 menekankan pendekatan organisasi materi pelajaran: kelompok pembinaan Pancasila, pengetahuan dasar, dan kecakapan khusus. Muatan materi pelajaran bersifat teoritis, tidak mengaitkan dengan permasalahan faktual di lapangan.

Pada masa ini siswa hanya berperan sebagai pribadi yang masif, dengan hanya menghapal teori-teori yang ada, tanpa ada pengaplikasian dari teori tersebut. Aspek afektif dan psikomotorik tidak ditonjolkan pada kurikulum ini. Praktis, kurikulum ini hanya menekankan pembentukkan peserta didik hanya dari segi intelektualnya saja.

${ }^{19} \mathrm{https}$ // makalah-ibnu.blogspot.com/2009/12/sistem-pendidikan-pada-masa-ordelama.html\#axzz6GWrGyL6G, Diakses 11 Desember 2020 


\section{Kurikulum 1975}

Kurikulum 1975 menekankan pada tujuan, agar pendidikan lebih efektif dan efisien berdasar MBO (management by objective). Metode, materi, dan tujuan pengajaran dirinci dalam Prosedur Pengembangan Sistem Instruksional (PPSI), yang dikenal dengan istilah "satuan pelajaran", yaitu rencana pelajaran setiap satuan bahasan. Setiap satuan pelajaran dirinci menjadi : tujuan instruksional umum (TIU), tujuan instruksional khusus (TIK), materi pelajaran, alat pelajaran, kegiatan belajar-mengajar, dan evaluasi.

Pada kurikulum ini peran guru menjadi lebih penting, karena setiap guru wajib untuk membuat rincian tujuan yang ingin dicapai selama proses belajar-mengajar berlangsung. Tiap guru harus detail dalam perencanaan pelaksanaan program belajar mengajar. Setiap tatap muka telah di atur dan dijadwalkan sedari awal. Dengan kurikulum ini semua proses belajar mengajar menjadi sistematis dan bertahap.

\section{Kurikulum 1984}

Kurikulum 1984 mengusung "process skill approach". Proses menjadi lebih penting dalam pelaksanaan pendidikan. Peran siswa dalam kurikulum ini menjadi mengamati sesuatu, mengelompokkan, mendiskusikan, hingga melaporkan. Model ini disebut Cara Belajar Siswa Aktif (CBSA) atau Student Active Leaming (SAL). CBSA memposisikan guru sebagai fasilitator, sehingga bentuk kegiatan ceramah tidak lagi ditemukan dalam kurikulum ini. Pada kurikulum ini siswa diposisikan sebagai subjek dalam proses belajar mengajar. Siswa juga diperankan dalam pembentukkan suatu pengetahuan dengan diberi kesempatan untuk mengemukakan pendapat, bertanya, dan mendiskusikan sesuatu.

\section{Kurilukum 1994}

Kurikulum 1994 merupakan hasil upaya untuk memadukan kurikulum-kurikulum sebelumnya, terutama kurikulum 1975 dan 1984. Pada kurikulum ini bentuk opresi kepada siswa mulai terjadi dengan beratnya beban belajar siswa, dari muatan nasional sampai muatan lokal. Materi muatan lokal disesuaikan dengan kebutuhan daerah masing-masing, misalnya bahasa daerah kesenian, keterampilan daerah, dan lain-lain. ${ }^{20}$

Berbagai kepentingan kelompok-kelompok masyarakat juga mendesak agar isu-isu tertentu masuk dalam kurikulum. Akhirnya, Kurikulum 1994 menjelma menjadi kurikulum super padat. Siswa dihadapkan dengan banyaknya beban belajar yang harus mereka tuntaskan, dan mereka tidak memiliki pilihan untuk menerima atau tidak terhadap banyaknya beban belajar yang harus mereka hadapi.

\section{Pendidikan Pada Masa Reformasi}

Era reformasi telah memberikan ruang yang cukup besar bagi perumusan kebijakankebijakan pendidikan baru yang bersifat reformatif dan revolusioner. Bentuk kurikulum menjadi berbasis kompetensi. Begitu pula bentuk pelaksanaan pendidikan berubah dari sentralistik (orde lama) menjadi desentralistik. Pada masa ini pemerintah menjalankan

${ }^{20}$ Mustafa, Sejarah Pendidikan Islam di Indonesia. (Bandung: Pustaka Setia, 2001), 137. 
amanat UUD 1945 dengan memprioritaskan anggaran pendidikan sekurang-kurangnya $20 \%$ dari anggaran pendapatan belanja negara.

"Negara memprioritaskan anggaran pendidikan sekurang-kurangnya dua puluh persen $(20 \%)$ dari anggaran pendapatan dan belanja negara, serta dari anggaran pendapatan dan belanja daerah untuk memenuhi kebutuhan penyelenggaraan pendidikan nasional. $^{21}$

Dengan didasarkan oleh UU No. 22 tahun 1999 tentang pemerintahan daerah, yang diperkuat dengan UU No. 25 tahun 1999 tentang perimbangan keuangan pusat dan daerah, maka pendidikan digiring pada pengembangan lokalitas, di mana keberagaman sangat diperhatikan. Masyarakat dapat berperan aktif dalam pelaksanaan satuan pendidikan.

Pendidikan di era reformasi 1999 mengubah wajah sistem pendidikan Indonesia melalui UU No 22 tahun 1999, dengan ini pendidikan menjadi sektor pembangunan yang didesentralisasikan. Pemerintah memperkenalkan model "Manajemen Berbasis Sekolah". Sementara untuk mengimbangi kebutuhan akan sumber daya manusia yang berkualitas, maka dibuat sistem "Kurikulum Berbasis Kompetensi".

Memasuki tahun 2003 pemerintah membuat UU No.20 tahun 2003 tentang sistem pendidikan nasional menggantikan UU No 2 tahun 1989., dan sejak saat itu pendidikan dipahami sebagai:

"usaha sadar dan terencana untuk mewujudkan suasana belajar dan proses pembelajaran agar peserta didik secara aktif mengembangkan potensi dirinya untuk memiliki kekuatan spiritual keagamaan, pengendalian diri, kepribadian, kecerdasan, akhlak mulia, serta keterampilan yang diperlukan dirinya, masyarakat, bangsa dan Negara.

pendidikan di masa reformasi juga belum sepenuhnya dikatakan berhasil. Karena, pemerintah belum memberikan kebebasan sepenuhnya untuk mendesain pendidikan sesuai dengan kebutuhan dan kepentingan lokal, misalnya penentuan kelulusan siswa masih diatur dan ditentukan oleh pemerintah. Walaupun telah ada aturan yang mengatur posisi siswa sebagai subjek yang setara dengan guru, namun dalam pengaplikasiannya, guru masih menjadi pihak yang dominan dan mendominasi siswanya, sehingga dapat dikatakan bahwa pelaksanaan proses pendidikan Indonesia masih jauh dari dikatakan untuk memperjuangkan hak-hak siswa.

Ada beberapa kesalahan dalam pengelolaan pendidikan pada masa ini, telah melahirkan hasilnya yang pahit yakni:

a. Angkatan kerja yang tidak bisa berkompetisi dalam lapangan kerja pasar global.

b. Birokrasi yang lamban, korup dan tidak kreatif.

c. Masyarakat luas yang mudah bertindak anarkis.

d. Sumberdaya alam (terutama hutan) yang rusak parah.

e. Hutang Luar Negeri yang tak tertanggungkan.

f. Merajalelanya tokoh-tokoh pemimpin yang rendah moralnya. ${ }^{22}$

${ }^{21}$ Ricklefs, M.C, Sejarah Indonesia Modern 1200-2008. (Jakarta PT Serambi Ilmu Semesta, 2008$), 87$.

${ }^{22}$ Ibid., 
Adapun kurikulum-kurikulum yang dipakai pada masa reformasi yaitu sebagai berikut:

\section{Kurikulum Berbasis Kompetensi}

Pada pelaksanaan kurikulum ini, posisi siswa kembali ditempatkan sebagai subjek dalam proses pendidikan dengan terbukanya ruang diskusi untuk memperoleh suatu pengetahuan. Siswa justru dituntut untuk aktif dalam memperoleh informasi. Kembali peran guru diposisikan sebagai fasilitator dalam perolehan suatu informasi.

Kegiatan pembelajaran menggunakan pendekatan dan metode yang bervariasi, sumber belajar bukan hanya guru, tetapi juga sumber belajar lainnya yang memenuhi unsur edukatif. Hal ini mutlak diperlukan mengingat KBK juga memiliki visi untuk memperhatikan aspek afektif dan psikomotorik siswa sebagai subjek pendidikan. Berikut karakteristik utama KBK, yaitu:

a. Menekankan pencapaian kompetensi siswa, bukan tuntasnya materi.

b. Kurikulum dapat diperluas, diperdalam, dan disesuaikan dengan potensi siswa (normal, sedang, dan tinggi).

c. Berpusat pada siswa.

d. Orientasi pada proses dan hasil.

e. Pendekatan dan metode yang digunakan beragam dan bersifat kontekstual.

f. Guru bukan satu-satunya sumber ilmu pengetahuan.

g. Buku pelajaran bukan satu-satunya sumber belajar.

h. Belajar sepanjang hayat;

i. Belajar mengetahui (learning how to know),

j. Belajar melakukan (learning how to do),

k. Belajar menjadi diri sendiri (learning how to be),

1. Belajar hidup dalam keberagaman (learning how to live together). ${ }^{23}$

\section{Kurikulum Tingkat Satuan Pendidikan (KTSP) 2006}

Secara umum KTSP tidak jauh berbeda dengan KBK namun perbedaan yang menonjol terletak pada kewenangan dalam penyusunannya, yaitu mengacu pada desentralisasi sistem pendidikan. Pemerintah pusat menetapkan standar kompetensi dan kompetensi dasar, sedangkan sekolah dalam hal ini guru dituntut untuk mampu mengembangkan dalam bentuk silabus dan penilaiannya sesuai dengan kondisi sekolah dan daerahnya. ${ }^{24}$

Jadi pada kurikulum ini sekolah sebagai satuan pendidikan berhak untuk menyusun dan membuat silabus pendidikan sesuai dengan kepentingan siswa dan kepentingan lingkungan. KTSP lebih mendorong pada lokalitas pendidikan. Karena KTSP berdasar

${ }^{23}$ Syaripudin, Tatang dan Nur'aini. Landasan Pendidikan (Bandung: UPI PRESS, 2006), 82.

24Izhaman, Fitrial. (2013). Landasan Historis Pendidikan. [Online]. Tersedia:meyzzacompany.blogspot.com/2013/06/landasan-historis-pendidikan.html, Diakses 11 Desember, 2020 
pada pelaksanaan KBK, maka siswa juga diberikan kesempatan untuk memperoleh pengetahuan secara terbuka berdasarkan sistem ataupun silabus yang telah ditetapkan oleh masing-masing sekolah.

Dalam kurikulum ini, unsur pendidikan dikembalikan kepada tempatnya semula yaitu unsur teoritis dan praksis. Namun, dalam kurikulum ini unsur praksis lebih ditekankan dari pada unsur teoritis. Setiap kebijakan yang dibuat oleh satuan terkecil pendidikan dalam menentukan metode pembelajaran dan jenis mata ajar disesuaikan dengan kebutuhan siswa dan lingkungan sekitar.

\section{Kurikulum 2013}

Kurikulum menurut Undang-Undang Nomor 20 Tahun 2003 pasal 1 ayat 19 adalah: Seperangkat rencana dan pengaturan mengenai tujuan, isi dan bahan pelajaran serta cara yang digunakan sebagai penyelenggara kegiatan pembelajaran untuk mencapai tujuan pendidikan tertentu. ${ }^{25}$

Sedangkan Kurikulum 2013 adalah langkah lanjutan pengembangan kurkulum berbasis kompentensi yang telah dirintis pada tahun 2004 dan KTSP 2006 yang mencakup kompentensi sikap, pengetahuan dan keterampilan secara terpadu. ${ }^{26}$

Kurikulum 2013 yang berbasis karakter dan kompentensi lahir sebagai jawaban terhadap berbagai kritikan terhadap kurikulum 2006, serta sesuai dengan perkembangan kebutuhan dan dunia kerja. Kurikulum 2013 merupakan salah satu upaya pemerintah untuk mencapai keunggulan masyarakat bangsa dalam penguasaan teknologi sepert yang digariskan dalam haluan negara. Pengembangan kurikulum 2013 didasari oleh pemikiran tentang tantangan masa depan, persepsi masyarakat pengetahuan dan pedagogi, kompentensi masa depan, serta fenomena negatif yang mengemuka. ${ }^{27}$

1. Karateristik Kurikulum 2013

Terdapat sejumlah karakteristik kurikulum 2013 berdasarkan salinan lampiran Permendikbud No. 96 Tahun 2013, yang membedakan dengan kurikulum sebelumnya. Karakteristik tersebut adalah sebagai berikut:

a. Mengembanggkan keseimbangan antara pengembangan sikap spritual dan sosial, rasa ingin tahu, kreativitas, kerja sama dengan kemamuan intelektual dan psikomotorik.

b. Sekolah merupakan bagian dari masyarakat yang memberikan pengalaman belajar terencana dimana peserta didik menerapkan apa yang dipelajari disekolah ke masyarakat dan memanfaatkan masyarakat sebaga sumber belajar.

c. Mengembangkan sikap, pengetahuan dan keterampian serta menerapkan dalam berbagai situasi di sekolah dan masyarakat.

${ }^{25}$ Undang-Undang Nomor 20 Tahun 2003 tentang Sistem Pendidikan Nasional, Lembaran Negara Republik Indonesia Tahun 2003 Nomor 78.

${ }^{26}$ E Mulyasa, Pengembangan dan Implementasi Kurikulum 2013, (Bandung: Rosdakarya, (2013),163.

27Pedoman Pelatihan Implementasi Kurikulum 2013, Kementarian Pendidkan dan Kebudayaan Tahun 2013, 4 . 
d. Memberi waktu yang cukup leluasa untuk mengembangkan berbagai sikap, pengetahuan dan keterampilan.

e. Kompetensi dinyatakan dalam bentuk kompetensi inti kelas yang dirinci lebih lanjut dalam kompetensi dasa mata pelajaran.

f. Kompentensi inti kelas menjadi unsur pengorganisasian kompentensi dasar, dimana semua kompetensi dasar dan proses pembelajaran dikembangkan mencapai kompetensi yang dinyatakan dalam kompetensi inti.

g. Kompetensi dasar dikembangkan didasarkan pada prinsip akumulatif, saling memperkuat dan memperkaya antar mata pelajaran dan jenjang pendidikan. ${ }^{28}$

Dari sekian banyak unsur sumber daya pendidikan, kurikulum merupakan salah satu unsur yang bisa memberikan kontribusi yang signifikan untuk mewujudkan proses berkembangnya kualitas potensi peserta didik. Kurikulum 2013 yang dikembangkan dengan berbasis pada kompetensi sangat diperlukan sebagai instrumen untuk mengarahkan peserta didik menjadi: (1) manusia berkualitas yang mampu dan proaktif menjawab tantangan zaman yang selalu berubah; dan (2) manusia terdidik yang beriman dan bertakwa kepada Tuhan Yang Maha Esa, berakhlak mulia, sehat, berilmu, cakap, kreatif, mandiri; dan (3) warga negara yang demokratis dan bertanggung jawab.

Pengembangan dan pelaksanaan kurikulum 2013 yang berbasis kompetensi merupakan salah satu strategi pembangunan pendidikan nasional sebagaimana yang diamanatkan dalam Undang-Undang Nomor 20 Tahun 2003 tentang Sistem Pendidikan Nasional. ${ }^{29}$

Kurikulum 2013 dalam dimensi proses adalah realisasi ide dan rancangan kurikulum menjadi suatu proses pembelajaran. Guru adalah tenaga kependidikan utama yang mengembangkan ide dan rancangan tersebut menjadi proses pembelajaran. Pemahaman guru tentang kurikulum akan menentukan rancangan guru (Rencana Program Pembelajaran/RPP) dan diterjemahkan ke dalam bentuk kegiatan pembelajaran. Peserta didik berhubungan langsung dengan apa yang dilakukan guru dalam kegiatan pembelajaran dan menjadi pengalaman langsung peserta didik. Apa yang dialami peserta didik akan menjadi hasil belajar pada dirinya dan menjadi hasil kurikulum. Oleh karena itu proses pembelajaran harus memberikan kesempatan yang luas kepada peserta didik untuk mengembangkan potensi dirinya menjadi hasil belajar yang sama atau lebih tinggi dari yang dinyatakan dalam Standar Kompetensi Lulusan.

Kurikulum 2013 yang berbasis kompetensi diarahkan pada pencapaian kompetensi yang dirumuskan dari Standar Kompentensi Lulusan. ${ }^{30}$ Demikian pula penilaian hasil belajar dan hasil kurikulum diukur dari pencapaian kompetensi. Keberhasilan kurikulum diartikan sebagai pencapaian kompetensi yang dirancang dalam dokumen kurikulum oleh seluruh peserta didik. Secara rinci karakteristik kurikulum 2013 yang berbasis kompetensi adalah sebagai berikut:

${ }^{28}$ Salinan Lampiran Permendikbud No 69 Tahun 2013 Tentang Kurikulum SMA-MA, 1.

${ }^{29} \mathrm{Ibid}, 2$.

${ }^{30}$ Pedoman Pelatihan Implementasi Kurikulum 2013, Kementerian, 1-7. 
1) Isi atau konten kurikulum adalah kompetensi yang dinyatakan dalam bentuk Kompetensi Inti (KI) mata pelajaran dan dirinci lebih lanjut ke dalam Kompetensi Dasar (KD).

2) Kompetensi Inti (KI) merupakan gambaran secara kategorial mengenai kompetensi yang harus dipelajari peserta didik untuk suatu jenjang sekolah, kelas, dan mata pelajaran

3) Kompetensi Dasar (KD) merupakan kompetensi yang dipelajari peserta didik untuk suatu mata pelajaran di kelas tertentu.

4) Penekanan kompetensi ranah sikap, keterampilan kognitif, keterampilan psikomotorik, dan pengetahuan untuk suatu satuan pendidikan dan mata pelajaran ditandai oleh banyaknya KD suatu mata pelajaran. Untuk SD pengembangan sikap menjadi kepedulian utama kurikulum.

5) Kompetensi Inti menjadi unsur organisatoris kompetensi bukan konsep, generalisasi, topik atau sesuatu yang berasal dari pendekatan "disciplinary-based curriculum" atau "content-based curriculum".

6) Kompetensi Dasar yang dikembangkan didasarkan pada prinsip akumulatif, saling memperkuat dan memperkaya antar mata pelajaran.

7) Proses pembelajaran didasarkan pada upaya menguasai kompetensi pada tingkat yang memuaskan dengan memperhatikan karakteristik konten kompetensi dimana pengetahuan adalah konten yang bersifat tuntas (mastery). Keterampilan kognitif dan psikomotorik adalah kemampuan penguasaan konten yang dapat dilatihkan. Sedangkan sikap adalah kemampuan penguasaan konten yang lebih sulit dikembangkan dan memerlukan proses pendidikan yang tidak langsung.

8) Penilaian hasil belajar mencakup seluruh aspek kompetensi, bersifat formatif dan hasilnya segera diikuti dengan pembelajaran remedial untuk memastikan penguasaan kompetensi pada tingkat memuaskan (Kriteria Ketuntasan Minimal/KKM dapat dijadikan tingkat memuaskan). ${ }^{31}$

9) Kompetensi adalah kemampuan seseorang untuk bersikap, menggunakan pengetahuan dan keterampilan untuk melaksanakan suatu tugas di sekolah, masyarakat, dan lingkungan dimana yang bersangkutan berinteraksi. Kurikulum 2013 dirancang untuk memberikan pengalaman belajar seluas-luasnya bagi peserta didik untuk mengembangkan sikap, keterampilan dan pengetahuan yang diperlukan untuk membangun kemampuan tersebut. Hasil dari pengalaman belajar tersebut adalah hasil belajar peserta didik yang menggambarkan manusia dengan kualitas yang dinyatakan dalam Standar Kompentensi Lulusan.

\section{Tujuan Kurikulum 2013}

Kurikulum 2013 bertujuan untuk mempersiapkan manusia Indonesia agar memiliki kemampuan hidup sebagai pribadi dan warga negara yang beriman, produktif, 
kreatif, inovatif dan efektif serta mampu berkontribusi pada kehidupan bermasyarakat berbangsa dan bernegara dan peradaban dunia. Dalam hal ini, pengembangan kurikulum 2013 difokuskan pada pembentukan kompetensi dan karakter peserta didik, berupa paduan pengetahuan, keterampilan dan sikap yang dapat di demontrasikan peserta didik sebagai wujud pemahaman terhadap konsep yang dipelajarinya secara konseptual. ${ }^{32}$

\section{Kebijakan Pendidikan Kabinet Kerja}

Menindaklanjuti arahan Presiden Republik Indonesia Joko Widodo dan Wakil Presiden Republik Indonesia Ma'ruf Amin untuk meningkatkan kualitas sumber daya manusia (SDM), Menteri Pendidikan dan Kebudayaan (Mendikbud) Nadiem Anwar Makarim, menetapkan empat program pokok kebijakan pendidikan "Merdeka Belajar". Program tersebut meliputi Ujian Sekolah Berstandar Nasional (USBN), Ujian Nasional (UN), Rencana Pelaksanaan Pembelajaran (RPP), dan Peraturan Penerimaan Peserta Didik Baru (PPDB) Zonasi.

Empat program pokok kebijakan pendidikan tersebut akan menjadi arah pembelajaran kedepan yang fokus pada arahan Bapak Presiden dan Wakil Presiden dalam meningkatkan kualitas sumber daya manusia ${ }^{33}$. Arah kebijakan baru penyelenggaraan USBN, kata Mendikbud, pada tahun 2020 akan diterapkan dengan ujian yang diselenggarakan hanya oleh sekolah. Ujian tersebut dilakukan untuk menilai kompetensi siswa yang dapat dilakukan dalam bentuk tes tertulis atau bentuk penilaian lainnya yang lebih komprehensif, seperti portofolio dan penugasan (tugas kelompok, karya tulis, dan sebagainya). "Dengan itu, guru dan sekolah lebih merdeka dalam penilaian hasil belajar siswa. Anggaran USBN sendiri dapat dialihkan untuk mengembangkan kapasitas guru dan sekolah, guna meningkatkan kualitas pembelajaran. ${ }^{34}$

Selanjutnya, mengenai ujian UN, tahun 2020 merupakan pelaksanaan UN untuk terakhir kalinya. "Penyelenggaraan UN tahun 2021, akan diubah menjadi Asesmen Kompetensi Minimum dan Survei Karakter, yang terdiri dari kemampuan bernalar menggunakan bahasa (literasi), kemampuan bernalar menggunakan matematika (numerasi), dan penguatan pendidikan karakter," jelas Mendikbud.

Pelaksanaan ujian tersebut akan dilakukan oleh siswa yang berada di tengah jenjang sekolah (misalnya kelas 4, 8, 11), sehingga dapat mendorong guru dan sekolah untuk memperbaiki mutu pembelajaran. Hasil ujian ini tidak digunakan untuk basis seleksi siswa ke jenjang selanjutnya. "Arah kebijakan ini juga mengacu pada praktik baik pada level internasional seperti PISA dan TIMSS," Sedangkan untuk penyusunan Rencana Pelaksanaan Pembelajaran (RPP), Kemendikbud akan menyederhanakannya dengan memangkas beberapa komponen. Dalam kebijakan baru tersebut, guru secara bebas dapat memilih, membuat, menggunakan, dan mengembangkan format RPP. Tiga komponen

\footnotetext{
${ }^{32}$ Mulyasa, Pengembangan dan Implementasi, 163.

${ }^{33}$ https:// news.detik.com/berita/d-4822012/keluarkan-4-program-merdeka-belajar-nadiem-inibaru-langkah-awal, Diakses 11 Desember 2020

${ }^{34}$ https://news.detik.com/berita/d-4822012/keluarkan-4-program-merdeka-belajar-nadiem-inibaru-langkah-awal, Diakses 11 Desember 2020
} 
inti RPP terdiri dari tujuan pembelajaran, kegiatan pembelajaran, dan asesmen. "Penulisan RPP dilakukan dengan efisien dan efektif sehingga guru memiliki lebih banyak waktu untuk mempersiapkan dan mengevaluasi proses pembelajaran itu sendiri. Satu halaman saja cukup," jelas Mendikbud.

Dalam penerimaan peserta didik baru (PPDB), Kemendikbud tetap menggunakan sistem zonasi dengan kebijakan yang lebih fleksibel untuk mengakomodasi ketimpangan akses dan kualitas di berbagai daerah. Komposisi PPDB jalur zonasi dapat menerima siswa minimal 50 persen, jalur afirmasi minimal 15 persen, dan jalur perpindahan maksimal 5 persen. Sedangkan untuk jalur prestasi atau sisa 0-30 persen lainnya disesuaikan dengan kondisi daerah. "Daerah berwenang menentukan proporsi final dan menetapkan wilayah zonasi ${ }^{35}$.

Mendikbud berharap pemerintah daerah dan pusat dapat bergerak bersama dalam memeratakan akses dan kualitas pendidikan "Pemerataan akses dan kualitas pendidikan perlu diiringi dengan inisiatif lainnya oleh pemerintah daerah, seperti redistribusi guru ke sekolah yang kekurangan guru ${ }^{36}$.

\section{Kesimpulan}

Historis pendidikan dari masa awal kemerdekaan hingga masa orde baru mengalami perubahan yang signfikan baik dalam sistem maupun komponen pendidikan yang terlibat didalamnya. Seperti yang telah dijelaskan pada pembahasan, bahwa pada masa orde baru pendidikan hanya berlangsung dari segi kuantitas tanpa diimbangi dengan perkembangan kualitas. Yang terpenting pada masa ini adalah menciptakan lulusan terdidik sebanyakbanyaknya tanpa menghasilkan kualitas pengajaran dan hasil didikan. Adapun kurikulum yang digunakan pada masa ini yaitu kurikulum 1968, kurikulum 1975, kurikulum 1984 dan kurikulum 1994. Namun pendidikan pada masa berikutnya pada masa orde baru belum dikatakan berhasil sepenuhnya, maka pada masa berikutnya masa reformasi diperlukan adanya pembenahan-pembenahan, baik dalam bidang kurikulum maupun dari segi tenaga pengajarnya. Kurikulum yang dipakai pada era reformasi ini yaitu Kurikulum Berbasis Kompetensi (KBK) dan Kurikulum Tingkat Satuan Pendidikan (KTSP) dan K13.

Landasan adalah suatu alas atau dasar pijakan dari sesuatu hal atau suatu titik tumpu atau titik tolak dari sesuatu hal atau suatu fundasi tempat berdirinya sesuatu hal. Sedangkan pendidikan merupakan segala pengalaman belajar yang berlangsung dalam segala lingkungan dan sepanjang hidup. Pendidikan adalah usaha sadar yang dilakukan oleh keluarga, masyarakat, dan pemerintah, melalui kegiatan bimbingan, pengajaran, dan/atau latihan, yang berlangsung di dalam dan luar sekolah sepanjang hayat, untuk mempersiapkan peserta didik agar dapat memainkan peranan dalam berbagai lingkungan hidup secara tepat di masa yang akan datang.

\footnotetext{
${ }^{35}$ https:// nasional.kontan.co.id/news/nadiem-makarim-program-merdeka-belajar-merupakansolusi-untuk-mengubah-pola-pikir?page $=$ all, Diakses 11 Desember 2020

${ }^{36} \mathrm{https}$ // nasional.kontan.co.id/news/nadiem-makarim-program-merdeka-belajar-merupakansolusi-untuk-mengubah-pola-pikir?page=all, Diakses 11 Desember 2020
} 
Diharapkan dengan telah dibahasnya landasan historis pendidikan, kita sebagai generasi penerus bangsa mampu menghargai para pahlawan pendidikan yang telah berjuang mempertahankan keberdaan pendidikan dalam situasi apapun, sehingga generasi penerus bangsa bisa berkaca dari perjuangan para pahlawan pendidikan untuk menuju pendidikan yang lebih baik di masa yang akan datang.

\section{Daftar Pustaka}

http://www.unindra.ac.id/?q=node/31, Diakses 11 Desember 2020

https://makalah-ibnu.blogspot.com/2009/12/sistem-pendidikan-pada-masa-orde lama.html\# axzz6GWrGyL6G, Diakses 11 Desember 2020

https://nasional.kontan.co.id/news/nadiem-makarim-program-merdeka-belajar merupakan-solusi-untuk-mengubah-pola-pikir?page=all, Diakses 11 Desember 2020

https://news.detik.com/berita/d-4822012/keluarkan-4-program-merdeka-belajarnadiem-ini-baru-langkah-awal, Diakses 11 Desember 2020

Izhaman, Fitrial. (2013). Landasan Historis Pendidikan. [Online]. Tersedia:meyzzacompany.blogspot.com/2013/06/landasan-historispendidikan.html, Diakses 11 Desember 2020

Kurikulum di Indonesia (meilanikasim.wordpress.com, diakses 11 Maret 2020

M.C, Ricklefs. Sejarah Indonesia Modern 1200-2008. Jakarta PT Serambi Ilmu Semesta, 2008

Mulyasa, E. Pengembangan dan Implementasi Kurikulum 2013. Bandung: Rosdakarya, 2013.

Mustafa. Sejarab Pendidikan Islam di Indonesia. Bandung: Pustaka Setia, 2001

Nugroho, Rianti. Pendidikan Indonesia: Harapan, Visi,dan Strategi. Jogjakarta: Pustaka Pelajar, 2008

Pedoman Pelatihan Implementasi Kurikulum 2013, Kementarian Pendidkan dan Kebudayaan Tahun 2013.

Said, Muh. dan Junima Affan, Mendidik dari Zaman ke Zaman. Bandung: Jemmars, 1999.

Salinan Lampiran Permendikbud No 69 Tahun 2013 Tentang Kurikulum SMA-MA

Syaripudin, Tatang dan Nur'aini. Landasan Pendidikan. Bandung: UPI PRESS, 2006. 
Moderasi Jurnal Studi Ilmu Pengetahuan Sosial, Volume I, No. 2, h. 56-78

Umasih. Ketika Kebijakan Orde Lama Memasuki Domain Pendidikan: Penyiapan Dan Kinerja Guru Sekolah Dasar Di Indonesia, Vol 24, No 1 (2014)

Undang-Undang Nomor 20 Tahun 2003 tentang Sistem Pendidikan Nasional, Lembaran Negara Republik Indonesia Tahun 2003 Nomor 78.

Yamin, Moh. Menggugat Pendidikan Indonesia. Jogjakarta: Ar Ruz, 2009 